\title{
Effects of a Gibberellin Inhibitor on Flowering, Vegetative Propagation, and Production of Rapid Generation Cycling Gladiolus for Potted Plant Production
}

\author{
Jaser A. Aljaser \\ Department of Biological Sciences, Faculty of Science, Kuwait University, \\ Sabah Al-Salem, Kuwait University City, Al-Shadadiyah, Kuwait
}

\author{
Neil O. Anderson \\ Department of Horticultural Science, 1970 Folwell Avenue, University of \\ Minnesota, St. Paul, MN 55108
}

Additional index words. cormels, corms, cycle 1 flowering, geophyte, Gladiolus $\times$ hybridus, growth retardants

\begin{abstract}
Gladiolus (Gladiolus $\times$ hybridus) is an asexually propagated, herbaceous perennial and an economically important cut flower crop. In commercial production, gladioli have tall flower stalks, which limit their use to cut flowers and annual garden plants. The gladiolus breeding program at the University of Minnesota has bred and selected rapid generation cycling (RGC) cycle 1 gladiolus, which can flower in $<1$ year from seed instead of the norm of 3 to 5 years (which are vegetatively propagated as corms). Gibberellin inhibitors, such as ancymidol, are used as plant growth retardants to control height in potted plants. Higher concentrations can inhibit flowering along with other negative side effects. The aim of this study was to investigate the growth, flowering, and corm/cormel production response of cycle 1 gladiolus to the gibberellin inhibitor, ancymidol $\left(0,100\right.$, and $400 \mathrm{mg} \cdot \mathrm{L}^{-1}$ soak) in comparison with noncycle 1 genotypes and commercial cultivars for potted gladiolus production. Cycle 1 genotypes flowered with all ancymidol concentrations while noncycle 1 genotypes had significantly fewer flowers or were completely nonflowering under higher concentrations. All tested genotypes had increased leaf width as ancymidol concentration increased. Conversely, flower stalk heights were shorter as the ancymidol concentration increased while the number of stalks was nonsignificant. Corms, cormel number, and fresh weights decreased in all genotypes except for one cycle 1 genotype, which had an increase in both corm number and fresh weight when treated with $100 \mathrm{mg} \cdot \mathrm{L}^{-1}$ ancymidol. Cycle 1 gladiolus are more resilient to this gibberellin inhibitor even at high concentrations and can potentially be used for gladiolus potted plant production.
\end{abstract}

Gladiolus (Gladiolus $\times$ hybridus Rodigas) is a member of the Iridaceae, native to South Africa (Goldblatt and Manning, 1998), and a major cut flower in the floriculture industry (ranked in the top 10 species). The 2018 wholesale farmgate value of cut flower gladiolus is $\$ 20.175 \mathrm{M}$ in the United States (U.S. Department of Agriculture, National Agricultural Statistics Service, 2019),

\footnotetext{
Received for publication 28 Oct. 2020. Accepted for publication 8 Jan. 2021.

Published online 4 February 2021.

This research has been supported by the Minnesota Agricultural Experiment Station, grants from the Minnesota Gladiolus Society, and a scholarship from the Kuwaiti Government.

J.A.A. is an Assistant Professor.

N.O.A. is a Professor.

N.O.A. is the corresponding author. E-mail: ander044@umn.edu.

This is an open access article distributed under the CC BY-NC-ND license (https://creativecommons. org/licenses/by-nc-nd/4.0/).
}

whereas in China, according to Forestry Bureau of China, the value was $\approx \$ 41 \mathrm{M}$ in 2011 (Fukai, 2012). It is also commonly grown as an ornamental garden plant (nonhardy in northern latitudes, USDA Z3-4) (Anderson et al., 2012).

Due to its economic importance, the University of Minnesota flower breeding program is developing cold-tolerant gladiolus for USDA Z3-4 (Anderson et al., 2012) with reduced generation cycling (Anderson et al., 2015). Other breeding objectives are dwarf gladiolus for potted plant production, RGC, and seed-propagated $\mathrm{F}_{1}$ hybrids. These would be new traits for this crop. RGC with the ability to flower from seed in $<1$ year (as early as 4-6 months) with a reduced juvenility and/or dormancy period is now a possibility (Anderson and Aljaser, 2019) due to 20 years of directed breeding and selection for flowering earliness (Anderson, 2019; Anderson et al., 2015); a U.S. Plant Utility Patent has been filed for breeding and selecting these phenotypes (Anderson and Aljaser,
2019). Such seed-propagated hybrids could also be forced to flower as vegetative clones without a cold treatment (Aljaser, 2020)

All gladiolus species are geophytes with corms (compressed stems) as underground storage organs (De Hertogh and Le Nard, 1993). In commercial production, gladioli are planted as mature (3-5 years old) corms (Dole and Wilkins, 2005). Gladioli are vegetatively propagated through daughter corms and cormels for commercial production. "Daughter corms" are defined as a specialized underground organ consisting of an enlarged stem axis with distinct nodes and internodes and enclosed by dry, scale-like leaves, whereas cormels refer to small corms arising from a mother corm (De Hertogh and Le Nard, 1993). Usually only one daughter corm is produced by the "mother corm" each year, whereas the number of cormels produced per year varies among cultivars (Cohat, 1993). Asexual propagation by any means (division, scooping, scoring, tissue culture) that produces the highest number of propagules (cormels, corms) as fast as possible is critical for meeting market demands for a clonal gladiolus cultivar. The need to increase the number of daughter corms and cormels quickly increases propagule pressure. Tissue culture provides an alternative method to produce cormels (Simonsen and Hildebrandt, 1971). The use of plant growth regulators, such as gibberellins, particularly $\mathrm{GA}_{3}$ and $\mathrm{GA}_{4+7}$ (Thomas and Hedden, 2006), has also been shown to increase cormel production. Gibberellins can increase the number of gladiolus cormels by means of exogenous applications (Khan et al., 2011).

Flowering in gladiolus is governed by factors such as corm size, vernalization, light intensity, long-day photoperiod, ambient temperature, and gibberellins (Ehrich, 2013; Kamenetsky et al., 2012). In geophytes such as Zantedeschia, storing the tubers resulted in a sharp increase in the endogenous gibberellin levels in the buds (Naor et al., 2008). Likewise, in gladiolus corms, gibberellin levels increase during cold storage while abscisic acid (ABA), an inhibitor, decreases in concentration (Wu et al., 2015). In addition, exogenous applications of gibberellins can hasten flowering (Sudhakar and Kumar, 2012; Tonecki, 1980).

Gibberellin inhibitors consist of a wide range of plant growth retardants. Their primary use in commercial plant production is to reduce plant height through decreased cell elongation and cell division (Rademacher, 1991). Commercial applications are used to restrict plant height and establish a uniform height in ornamental crops using an appropriate concentration of gibberellin inhibitors for bulbous crops, such as Hippeastrum (Miller et al., 2012).

The PGR [ancymidol: $\alpha$-cyclopropyl$\alpha$-(p-methoxyphenyl)-5-pyrimidinemethanol] is a pyrimidine analog. Its mode of action is blocking the monooxygenase enzyme that catalyzes ent-kaurene oxidation, a necessary step in the pathway between ent-kaurene and gibberellins (Rademacher, 1991). Ancymidol 
is applied at low rates ranging between 10 and $200 \mathrm{mg} \cdot \mathrm{L}^{-1}$ for foliar sprays and 0.15 to $0.5 \mathrm{mg}$ per $15.24 \mathrm{~cm}^{2}$ container for substrate drenches (Whipker and Evans, 2012). For gladiolus, a drench application rate of $1.5 \mathrm{mg}$ A-Rest per $1.89 \mathrm{~L}$ was reported to effectively reduce height (Shaw et al., 1991). Conversely, drench applications of other types of gibberellin inhibitors, such as $0.8 \% 2$-chloroethyltrimethylammonium chloride (CCC), resulted in increases of stem length, the number of florets per spike and slightly later flowering dates (Halevy and Shilo, 1970). These plant growth regulator compounds have not been tested on newly developed winterhardy and dwarf germplasms in the University of Minnesota gladiolus breeding program, as well as new cycle- 1 seedpropagated hybrids that flower in $<1$ year from sowing (Anderson, 2019; Anderson et al., 2015).

While gladiolus is currently valued as a cut flower and landscape ornamental, its long juvenile period and tall stature have made it unsuitable for potted plant production or as a bedding plant. Thus, there is a need to develop gladiolus plants with shorter juvenile periods and shorter statures both for breeding and genetic improvement of gladiolus as well as for potted plant production (Anderson and Aljaser, 2019). The University of Minnesota Flower Breeding and Genetic gladiolus program has the objective of producing new phenotypes of gladiolus with RGC, whereby as many as three cycles per year (where a cycle is equivalent to 1-year growth, dry down, and vernalization treatments) enables faster breeding and selecting (Anderson, 2019; Anderson et al., 2015; Anderson and Aljaser, 2019). In gladiolus, the period of seed to flower may encompass 3 to 5 years (Anderson, 2019). Anderson et al. (2015) created an RGC program for gladiolus that included enhanced selection of seedpropagated hybrids for early germination, early leaf unfolding, high leaf numbers in RGC 1 to 3, early flowering stalk emergence, and hastened flowering (flower bud initiation and development). All selection was done under standard growing conditions for the species, i.e., seed germination (2-7 weeks) in glasshouse mist systems $\left(21{ }^{\circ} \mathrm{C}\right.$ day/night $)$ followed by subsequent growth of transplants for 7 weeks in glasshouses $\left(24 / 20{ }^{\circ} \mathrm{C}\right.$ day/ night; inductive long-day photoperiods for flowering, $\geq 150 \mu \mathrm{mol} \cdot \mathrm{m}^{-2} \cdot \mathrm{s}^{-1}, 0600-2200$ $\mathrm{HR})$. Several genotypes were selected that flowered $<1$ year from seed in cycle 1 , meaning they did not require a vernalization period to mobilize GA and breakdown ABA concentrations. Because these unique hybrids were bred and selected without vernalization treatments, it is unknown whether these genotypes have the same response to GA inhibitors based on published literature on geophytes. The objective of this study was to demonstrate cycle 1 gladiolus genotypic response to a GA inhibitor for flowering, vegetative propagation production (corm and cormels), and their overall use for potted plant production of gladiolus. The null hypothesis was: $\mathrm{H}_{\mathrm{o}}=$ Treatment of ancymidol negatively impact gladiolus plant growth and flowering capability. The alternative hypothesis was: $\mathrm{H}_{\mathrm{A}}=$ Ancymidol concentrations positively impact gladiolus plant growth and flowering capability.

\section{Material and Methods}

Plant material. Seven gladiolus genotypes (vegetative clones) were used in this experiment. Two genotypes were commercial cultivars, 'Amsterdam' and 'Bananarama', which served as controls (comparisons). Flowering size corms of 'Amsterdam' and 'Bananarama' were obtained from Noweta Gardens (Table 1) during 2017 and had been produced in the same field conditions by the producer. 'Amsterdam' is a white-colored gladiolus that is a hybrid cultivar derived from unknown parents bred by J. and P. Snoek and Sons, Ltd. (Flevoland, The Netherlands) in 1992 (North America Gladiolus Counsel, 1999). 'Bananarama' is a new yellow-colored cultivar bred by Coöperatieve Kwekersvereniging "For Ever" U.A. and released in 2013 (Saint Maarten, The Netherlands; KAVB, 2014). On receipt of mature commercial corms with flowering capacity, they were cooled at $2{ }^{\circ} \mathrm{C}$ in darkness (Widmer, 1958) for $>1000 \mathrm{~h}$ before experimentation. Five University of Minnesota RGC gladiolus breeding lines were also tested: RGC-Genotype 1, RGC-Genotype 2, RGC-Genotype 3, RGC-Genotype 4, and RGC-Genotype 5 (Table 1). All RGC hybrid cormels were produced in the same greenhouse selection environment (Anderson et al., 2015) and were capable of flowering. Thus, RGC cormels are physiologically equivalent to the mature commercial corms for flowering capacity. As many RGC hybrid cormels as possible were obtained and vernalized along with the commercial cultivars for the same duration before the commencement of this experiment.

Treatments. Three treatments $(0,100$, and $\left.400 \mathrm{mg} \cdot \mathrm{L}^{-1}\right)$ of the gibberellin inhibitor ancymidol (A-Rest $0.0264 \%$ a.i.; SePRO Corp., Carmel, IN) were used (Table 1). All corms were soaked in the solutions for a period of $24 \mathrm{~h}$ before planting. There were $\mathrm{n}=$ 4 to 8 replications/genotype, depending on the availability of cormels from the RGC genotypes (Table 1). Thus, this experiment was an unbalanced design.

Greenhouse growing conditions. After $24 \mathrm{~h}$ of treatment, corms were planted into $1679.8 \mathrm{~cm}^{2}$ square, deep pots (Belden Plastics, St. Paul. MN) in week 23 (2017) and grown for 18 weeks. Containers were filled with a peatmoss based on soilless substrate (SunGrow SS\#8-F2-RSi; Sun Gro Horticulture, Agawam. MA). The corms were grown in a long-day photoperiod (08001600 HR supplied by 400-W high-pressure sodium lamps +2200 to $0200 \mathrm{HR}$ night interruption, $\left.>150 \mu \mathrm{mol} \cdot \mathrm{m}^{-2} \cdot \mathrm{s}^{-1}\right)$ at a minimum setpoint of $18^{\circ} \mathrm{C}$ (day/night), $70 \%$ to $80 \%$ relative humidity, with irrigation accomplished using constant liquid feed of $125 \mathrm{mg} \cdot \mathrm{L}^{-1} \mathrm{~N}$ from water-soluble $20 \mathrm{~N}$ 4.4P-16.6K (Peters Professional 20-10-20 peat-lite; ICL Fertilizers, Tel-Aviv, Israel) and deionized water on weekends. Standard fungicide drenches and insecticides were applied either monthly or as needed, respectively.

Data collected. Foliage height $(\mathrm{cm})$ was recorded at the peak of highest growth (measured from soil line to the tip of the uppermost leaf), flower stalk height ( $\mathrm{cm}$; measured as length from the uppermost leaf to the tip of the uppermost floral bud), flowering $(+/-)$, and leaf width $(\mathrm{cm})$ for widest leaf on each replicate. At the termination of the experiment, the number of corms and cormels were counted for production purposes and their respective fresh weights $(\mathrm{g})$ recorded.

Statistical analysis. Replicates were arranged in a complete random design, and all quantitative data were analyzed as unbalanced analysis of variance and Tukey's honestly significant difference mean separations at $P \leq 0.05$ using JMP 13 statistical software (Campus Drive, Cary, NC). Chisquares $\left(\chi^{2}\right)$ were calculated using a $1: 1: 1 \chi^{2}$ test ratio for equal distribution of flowering response among the three different ancymidol treatments $\left(0,100\right.$, and $\left.400 \mathrm{mg} \cdot \mathrm{L}^{-1}\right)$.

Table 1 . Number of replicates per treatment $\left(0,100\right.$, and $400 \mathrm{mg} \cdot \mathrm{L}^{-1}$ of ancymidol) and commercial or breeding source of the tested Gladiolus genotypes.

\begin{tabular}{|c|c|c|c|c|}
\hline \multirow[b]{2}{*}{ Genotype } & \multicolumn{3}{|c|}{ No. of replicates / treatment of ancymidol concn $\left(\mathrm{mg} \cdot \mathrm{L}^{-1}\right)$} & \multirow[b]{2}{*}{ Commercial or Breeding Source } \\
\hline & 0 (Control) & 100 & 400 & \\
\hline 'Amsterdam' & 8 & 8 & 8 & Noweta Gardens, Inc., Three Rivers, MI \\
\hline 'Bananarama' & 8 & 8 & 8 & Noweta Gardens, Inc., Three Rivers, MI \\
\hline RGC-1 & 4 & 4 & 4 & University of Minnesota, St. Paul, MN \\
\hline RGC-2 & 4 & 4 & 4 & University of Minnesota, St. Paul, MN \\
\hline RGC-3 & 7 & 7 & 7 & University of Minnesota, St. Paul, MN \\
\hline RGC-4 & 4 & 4 & 4 & University of Minnesota, St. Paul, MN \\
\hline RGC-5 & 5 & 5 & 5 & University of Minnesota, St. Paul, MN \\
\hline
\end{tabular}




\section{Results}

Ancymidol treatments resulted in variation in flowering between genotypes (Table 2). 'Amsterdam' and 'Bananarama' did not flower even after 18 weeks from corm planting in pots in comparison with control, which flowered in 10 and 11 weeks, respectively (Table 3). Genotype RGC-1 did not flower in all treatments, whereas RGC-2, RGC-3, RGC-4, and RGC-5 all flowered even at the highest ancymidol concentration, yet with variation in number of flowering plants in each treatment (Table 2). All flowering genotypes were not significantly different in 1:1:1 $\chi^{2}$ except for 'Bananarama' (Table 2). RGC-2, RGC-3, RGC-4, and RGC-5 genotypes, which flowered at high ancymidol concentration and were delayed in flowering by 1 to 2 weeks from the control (Table 3).

Plant height ranged from 19 to $108 \mathrm{~cm}$ (Table 4). Ancymidol significantly decreased plant height in the higher concentrations in all tested genotypes in exception of RGC-4 in which $100 \mathrm{mg} \cdot \mathrm{L}^{-1}(105.3 \mathrm{~cm}$ in height) was not statistically different from $0 \mathrm{mg} \cdot \mathrm{L}^{-1}$ treatment (106.0 cm in height) (Table 4). Both the number of stalks and leaf width were significantly different in the genotype, while in the treatment, leaf width was significantly increased in width with the increase of ancymidol concentration, ranging from 1.5 to 5.6 $\mathrm{cm}$ (Table 4). Corms and cormels were harvested after all plants senesced. They ranged in number from 1.0 to 8.0 with mean fresh weights of 3.7 to $40.8 \mathrm{~g}$ (Table 4 ).

\section{Discussion}

Gibberellin inhibitors such as ancymidol and paclobutrazol are reported to delay flowering in Tulipa (McDaniel, 1990), Lilium (Bailey and Miller, 1989), and Gladiolus (Ahmad et al., 2014). However, high concentrations of ancymidol resulted in completely inhibiting flowering in 'Bananarama' (Fig. 1), as it was the only genotype that flowered in the
$0 \mathrm{mg} \cdot \mathrm{L}^{-1}$ (control) treatment with complete lack of flowering in the other two treatments (100 and $400 \mathrm{mg} \cdot \mathrm{L}^{-1}$ ancymidol). This was also reported in different Watsonia species, as dipping the corms in $0.5,1$, and $2 \mathrm{mg}$ of paclobutrazol produced nonflowering plants. However, post-planting applications of 5, 10, and $25 \mathrm{mg}$ of paclobutrazol resulted in flowering Watsonia as marketable potted plants (Ascough et al., 2006). Treatments of exogenous gibberellins after pretreatment with paclobutrazol in Tulipa reversed the influence of paclobutrazol and promoted flowering (Rebers et al., 1994). This demonstrates the importance of gibberellins in the geophytic flowering pathway (Naor et al., 2008). Furthermore, RGC-2, RGC-3, RGC-4, and RGC-5 genotypes, which flowered at high ancymidol concentration were delayed in flowering by 1 to 2 weeks from the control (Table 3 ). This has been demonstrated using paclobutrazol on gladiolus, which resulted in delayed flowering as the concentration increased (Milandri et al., 2008) However, the RGC-3, RGC-4, and

Table 2. Influence of ancymidol concentrations $\left(0,100\right.$, and $\left.400 \mathrm{mg} \cdot \mathrm{L}^{-1}\right)$ on the number $(\mathrm{n})$ of flowering plants (frequency of flowering) and $1: 1: 1 \chi^{2}$ test ratios of the tested Gladiolus genotypes.

\begin{tabular}{|c|c|c|c|c|c|c|}
\hline \multirow[b]{2}{*}{ Genotype } & \multicolumn{4}{|c|}{ No. of flowering plants in ancymidol $\left(\mathrm{mg} \cdot \mathrm{L}^{-1}\right)$} & \multirow[b]{2}{*}{$1: 1: 1 \chi^{2}$} & \multirow[b]{2}{*}{ Significance } \\
\hline & $\mathrm{n}$ & 0 (control) & 100 & 400 & & \\
\hline 'Bananarama' & 24 & 5 & 0 & 0 & 9.98 & $* *$ \\
\hline RGC-3 & 21 & 6 & 1 & 5 & 3.50 & NS \\
\hline RGC-4 & 12 & 4 & 4 & 2 & 0.80 & NS \\
\hline RGC-5 & 15 & 5 & 1 & 3 & 2.67 & NS \\
\hline Cycle 1 & 48 & 15 & 6 & 10 & 3.94 & NS \\
\hline
\end{tabular}

${ }_{\mathrm{N} \text { N, }}^{* *}$ Nonsignificant or significant at $P=0.01$, respectively.

${ }^{\mathrm{y}}$ Not estimable due to no flowering in all replicates.

Table 3. Influence of ancymidol concentrations $\left(0,100\right.$, and $\left.400 \mathrm{mg} \cdot \mathrm{L}^{-1}\right)$ on the number $(\mathrm{n})$ of flowering plants (frequency of flowering) and mean number of weeks reached to flowering in each genotypes of the tested Gladiolus genotypes.

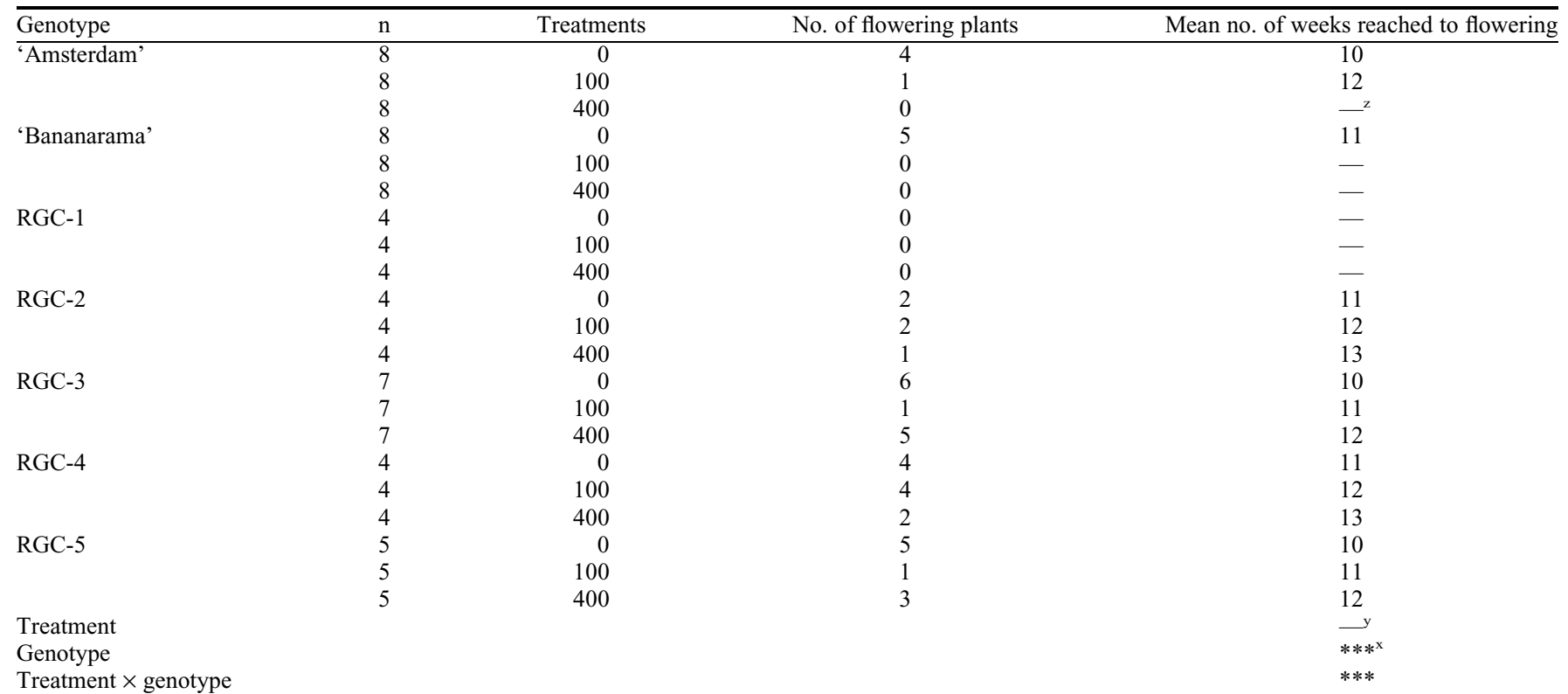

${ }^{\mathrm{z}}$ Not estimable due to no flowering in all replicates.

${ }^{\mathrm{y}}$ Not estimable due to the number of nonflowering genotypes.

${ }^{\mathrm{x}}$ Analysis of variance for NS or $* * *$ (nonsignificant or significant at $P=0.001$, respectively). 
Table 4. Mean plant height (cm), flower stalk height $(\mathrm{cm})$, number of stalks, leaf width $(\mathrm{cm})$, no. of corms, fresh weight (FW) of corms (g), number of cormels, and FW of cormels $(\mathrm{g})$ for seven gladiolus genotype corms treated with different concentrations of ancymidol $\left(0,100\right.$, and $\left.400 \mathrm{mg} \cdot \mathrm{L}^{-1}\right)$.

\begin{tabular}{|c|c|c|c|c|c|c|c|c|c|}
\hline Genotype & $\begin{array}{l}\text { Ancymidol } \\
\text { treatments }\end{array}$ & $\begin{array}{l}\text { Plant ht } \\
(\mathrm{cm})\end{array}$ & $\begin{array}{c}\text { Flower stalk } \\
\text { ht }(\mathrm{cm})\end{array}$ & No. of stalks & $\begin{array}{c}\text { Leaf } \\
\text { width }(\mathrm{cm})\end{array}$ & $\begin{array}{l}\text { No. of } \\
\text { corms }\end{array}$ & FW of corms (g) & No. of cormels & $\mathrm{FW}$ of cormels (g) \\
\hline \multirow{2}{*}{ 'Amsterdam' } & 100 & $78.0 \mathrm{cde}$ & $80.0 \mathrm{abc}$ & $2.0 \mathrm{bc}$ & $5.6 \mathrm{a}$ & $1.9 \mathrm{c}$ & $18.5 \mathrm{de}$ & $0.0 \mathrm{~b}$ & $-^{x}$ \\
\hline & 400 & $52.4 \mathrm{fg}$ & $-^{\mathrm{y}}$ & $1.6 \mathrm{bc}$ & $4.9 \mathrm{abcd}$ & $2.0 \mathrm{c}$ & $8.4 \mathrm{e}$ & $0.0 \mathrm{~b}$ & $-^{x}$ \\
\hline \multirow{2}{*}{ 'Bananarama' } & 100 & 62.9 ef & $\smile^{y}$ & $2.0 \mathrm{bc}$ & $5.2 \mathrm{ab}$ & $2.0 \mathrm{c}$ & $19.3 \mathrm{cde}$ & $0.0 \mathrm{~b}$ & $-^{x}$ \\
\hline & 400 & $40.7 \mathrm{~g}$ & $-\mathrm{y}$ & $1.7 \mathrm{bc}$ & $5.1 \mathrm{abc}$ & $1.8 \mathrm{c}$ & $17.1 \mathrm{de}$ & $0.0 \mathrm{~b}$ & $-^{x}$ \\
\hline RGC-1 & 0 & $101.5 \mathrm{abc}$ & $-\mathrm{y}$ & $3.0 \mathrm{abc}$ & $2.2 \mathrm{hi}$ & $3.0 \mathrm{bc}$ & $29.2 \mathrm{abcd}$ & $2.5 \mathrm{~b}$ & 1.4 \\
\hline \multirow[t]{3}{*}{ RGC-2 } & 0 & 83.3 abcde & $56.0 \mathrm{c}$ & $4.0 \mathrm{abc}$ & 2.6 fghi & $3.3 \mathrm{bc}$ & $32.6 \mathrm{abcd}$ & $2.7 \mathrm{~b}$ & 0.3 \\
\hline & 100 & $56.3 \mathrm{efg}$ & $55.5 \mathrm{c}$ & $2.8 \mathrm{bc}$ & $2.6 \mathrm{ghi}$ & $3.8 \mathrm{bc}$ & $17.2 \mathrm{de}$ & $0.0 \mathrm{~b}$ & $-^{x}$ \\
\hline & 400 & $33.5 \mathrm{~g}$ & $56.0 \mathrm{c}$ & $1.3 \mathrm{bc}$ & $2.2 \mathrm{hi}$ & $2.3 \mathrm{c}$ & $8.5 \mathrm{e}$ & $0.0 \mathrm{~b}$ & $-^{x}$ \\
\hline \multirow[t]{3}{*}{ RGC-3 } & 0 & $108.0 \mathrm{a}$ & $121.2 \mathrm{a}$ & $1.3 \mathrm{bc}$ & $3.7 \mathrm{defg}$ & $1.3 \mathrm{c}$ & $26.1 \mathrm{abcd}$ & $24.0 \mathrm{a}$ & 4.1 \\
\hline & 100 & $75.7 \mathrm{cdef}$ & $107.0 \mathrm{abc}$ & $1.8 \mathrm{bc}$ & 4.4 bcde & $2.0 \mathrm{c}$ & $26.1 \mathrm{abcd}$ & $7.5 \mathrm{~b}$ & 1.6 \\
\hline & 400 & $67.0 \mathrm{def}$ & $65.0 \mathrm{c}$ & $1.0 \mathrm{c}$ & $4.1 \mathrm{cdef}$ & $1.5 \mathrm{c}$ & 21.2 bcde & $2.8 \mathrm{~b}$ & 0.9 \\
\hline RGC-4 & 0 & $106.0 \mathrm{a}$ & $113.0 \mathrm{ab}$ & $4.0 \mathrm{ab}$ & 3.7 defgh & $3.5 \mathrm{bc}$ & $37.6 \mathrm{abc}$ & $1.3 \mathrm{~b}$ & 0.2 \\
\hline Treatment & & $* * *$ & - $^{\mathrm{w}}$ & NS & $* * *$ & * & $* * *$ & ** & $\mathrm{C}^{\mathrm{w}}$ \\
\hline Genotype & & $* * *$ & $* * *$ & $* * *$ & $* * *$ & $* * *$ & $* * *$ & $* * *$ & ${ }^{\mathrm{w}}$ \\
\hline Treatment $\times$ genotype & & $* * *$ & NS & NS & $* * *$ & NS & NS & $* * *$ & $-^{\mathrm{w}}$ \\
\hline
\end{tabular}

${ }^{\mathrm{z}}$ Means within a column not followed by the same letter are significantly different at $P \leq 0.05$ using Tukey's honestly significant difference means comparison.

${ }^{\mathrm{y}}$ No production of cormels.

${ }^{\mathrm{x}}$ Nonflowering.

${ }^{\mathrm{w}}$ Not estimable due to the number of nonflowering genotypes.

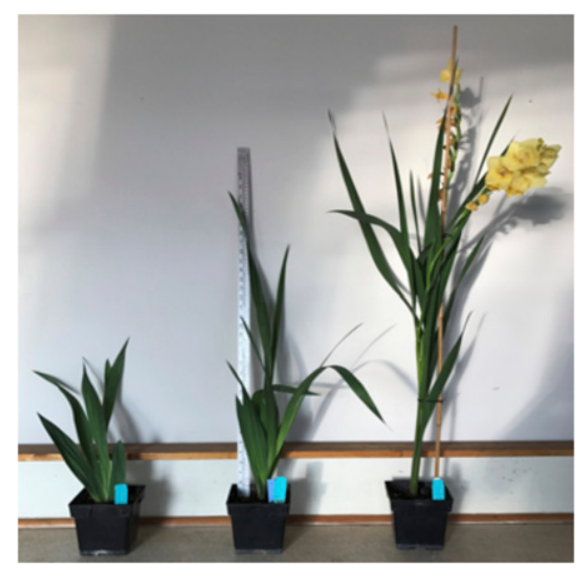

Fig. 1. 'Bananarama' gladiolus treated with ancymidol concentrations of 400,100 , and $0 \mathrm{mg} \cdot \mathrm{L}^{-1}$, left to right respectively. Photo credit: Jaser Aljaser.

RGC-5 genotypes are different in response because they are bred to be cycle 1 gladiolus with flowering in less than 1 year from sowing, all of which show short dormancy (Aljaser, 2020). These are genotypically different in response to commercial gladioli with deep dormancy (Kumar and Raju, 2007) overcome only with a cooling period. Pooled data for all genotypes were significantly different in flowering response (did not fit the $1: 1: 1 \chi^{2}$ ) as well for pooled noncycle 1 genotypes ('Amsterdam', 'Bananarama', RGC-1, and RGC-2) (Table 2). However, no differences were found with three of four cycle 1 genotypes (RGC-3, RGC-4, and RGC-5), indicating a complete lack of effect from the ancymidol treatment. This difference among RGC genotypes is most likely genetic in nature, although further testing would be required to determine the exact causal gene(s). Nonetheless, the parents and RGC3 to RGC5 are novel genotypes in gladiolus and will be used to enhance development of dwarf, seed-propagated cycle 1 selections that flower in $<1$ year from sowing. The reduction of plant height (Table 4) matches the reports of gladiolus using flurprimidol (Ahmad et al., 2014). Because gibberellin inhibitors are used to control the plant height by reducing gibberellin biosynthesis, this leads to limiting cell expansion and, thus, affecting plant height (Cosgrove and Sovonick-Dunford, 1989). The application of ancymidol, paclobutrazol and uniconazole decreased lily plant height even with a 1-minute dip at different concentrations (Ranwala et al., 2002). In addition to plant height, the flower stalk height was also decreased by ancymidol in 'Amsterdam', RGC-3, RGC-4, and RGC-5, whereas the flower stalk height of RGC-4 was not influenced by ancymidol treatments and the height was almost identical in all treatments. In RGC-3 and RGC-5, the $400 \mathrm{mg} \cdot \mathrm{L}^{-1}$ ancymidol concentration resulted in more marketable gladiolus for potted production in terms of plant height and flowering capability (Fig. 2). In freesia, Freesia $\times$ hybrida, dipping corms in $200 \mathrm{mg} \cdot \mathrm{L}^{-1}$ of ancymidol was also reported to reduce flower stalk height (Berghoef and Zevenbergen, 1989). In genotype RGC-1 and RGC-2, the number of stalks decreased significantly as ancymidol concentration increased, whereas only RGC-4 had an increase in the number of stalks. However, low concentrations (10 and $20 \mathrm{mg} \cdot \mathrm{L}^{-1}$ ) of paclobutrazol on Ornithogalum thyrsoides (a bulbous geophyte) increased the number of spikes per plant (Banswal, 2012). This indicates that increased levels of gibberellin inhibitors may influence the number of emerging stalks by genotype and species level.

Leaf width was significantly increased with ancymidol treatment, ranging from 1.5 to $5.6 \mathrm{~cm}$ (Table 4). Ancymidol at $100 \mathrm{mg} \cdot \mathrm{L}^{-1}$ resulted in the leaves with widest length that were wider than both the control and 400 $\mathrm{mg} \cdot \mathrm{L}^{-1}$ treatments in all genotypes with the exception of RGC-2 (Table 4). This increase in leaf width does not necessarily mean a corollary increase in leaf area. As reported by Bailey and Miller (1989), gibberellin inhibitors tend to reduce whole leaf area with increased applied concentration in Lilium longiflorum 'Nellie White' as well as Freesia ×hybrida (De Hertogh and Milks, 1989).

The number of corms showed variation with respect to treatment with $100 \mathrm{mg} \cdot \mathrm{L}^{-1}$ significantly increased the number of corms only in RGC-4 and RGC-5. However, the corollary corm weight did not increase, as the control treatment resulted in the highest fresh weight of all genotypes (Table 4). Similar results were reported for gladiolus (Ahmad et al., 2014). On the other hand, the number of cormels and fresh weight did not increase in number and weight. Likewise, the number of cormels decreased in those genotypes producing cormels. The decrease in number of 


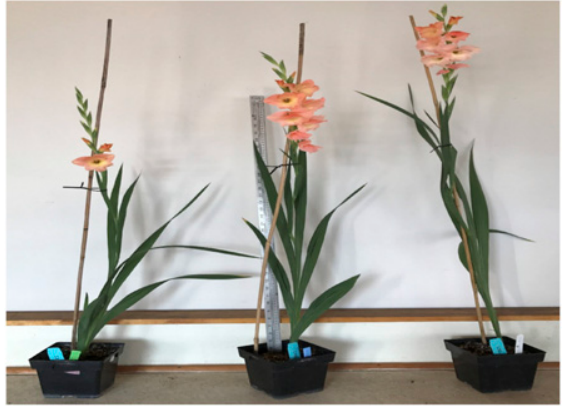

Fig. 2. Rapid Generation Cycling (RGC) RGC-3 gladiolus treated with ancymidol concentrations of 400,100 , and $0 \mathrm{mg} \cdot \mathrm{L}^{-1}$, left to right respectively. Photo credit: Jaser Aljaser.

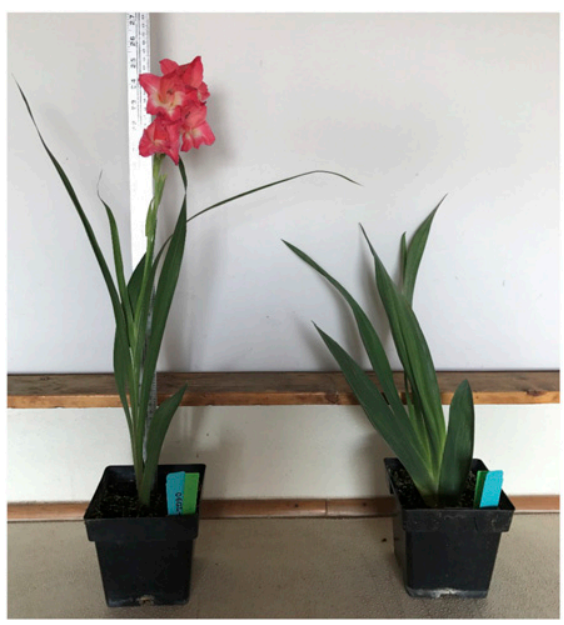

Fig. 3. Gladiolus treated with ancymidol concentration of $400 \mathrm{mg} \cdot \mathrm{L}^{-1}$. RGC-2 reached to flowering (left), whereas 'Bananarama' remained in vegetative state (right). Photo credit: Jaser Aljaser.

harvested cormels and fresh weight was similar to previous reports of gibberellin inhibitors in gladiolus, where concentrations as low as $10 \mathrm{mg} \cdot \mathrm{L}^{-1}$ paclobutrazol decreased cormel formation at the expense of increasing corm swelling in tissue culture (Steinitz and Lilien-Kipnis, 1989). This could mean the corm-cormel relationship is quantitative vs. qualitative, as gibberellin inhibitors influence a reduction in the number of cormels and corms. However, a recent study on corm and cormel formation was linked to the GhAGPL1 gene, indicating the role of ADPglucose pyrophosphorylase (AGPase) in starch accumulation, as silencing GhAGPL1 resulted in a reduction of corms and cormels (Seng and Wu et al., 2017). Therefore, the role of ancymidol as a gibberellin inhibitor could be hypothesized to interrupt the starch accumulation in corms and cormels, thus resulting in a reduction in weight. Future studies will be directed to answer this question.

In conclusion, gibberellin inhibitors such as ancymidol should be applied at precise concentrations for each genotype, as higher concentrations could result in failure to flower and reduce the fresh weight of both corms and cormels, which are essential for gladiolus floral production in the market. The desirable ideotype in producing potted gladiolus includes the plant height matching the aesthetic ratio of $1.5 \times$ to $2 \times$ the container diameter or height (whichever is greater) with $\geq 5$ leaves, possessing $\geq 7$ florets that open fully into a decorative floret size (8.9$11.4 \mathrm{~cm}$ ) (Anderson and Aljaser, 2019; Okubo and Sochacki, 2012). The tested cycle 1 gladioli have an increased tolerance of higher concentrations of gibberellin inhibitors, such as ancymidol, to reduce plant height. Such RGC gladioli are still able to flower, unlike noncycle 1 gladiolus genotypes, which exhibit reduced height and significantly less flowering capability at higher gibberellin inhibitor concentration (Fig. 3). Therefore, the recommended ancymidol concentration for non-cycle 1 gladiolus should not exceed $100 \mathrm{mg} \cdot \mathrm{L}^{-1}$, whereas cycle 1 gladiolus may tolerate as high as 100 $\mathrm{mg} \cdot \mathrm{L}^{-1}$ for potted gladiolus production. The use of gladiolus RGC genotypes with the addition of gibberellin inhibitors can achieve the desirable objective for plant height matching the aesthetic ratio for gladiolus potted plant production. Although flowering was eliminated in the commercial, non-RGC gladiolus cultivars tested at either $100 \mathrm{mg} \cdot \mathrm{L}^{-1}$ or $400 \mathrm{mg} \cdot \mathrm{L}^{-1}$ ancymidol (Table 4), a reduction in plant height was realized with flowering (Table 4; Fig. 1). Thus, additional cultivars could be tested with gibberellin inhibitors to potentially find genotypes that will flower with reduced plant height. However, the greatest potential resides in the RGC gladioli to achieve the target height for gladiolus potted plant production; RGC-2 would represent the ideal height gladiolus potted plant, foliage display, and flowering stalk height (Fig. 2; Table 4).

Further research will be conducted at lower concentrations to determine the recommended concentration to achieve the appropriate concentration for gladiolus potted production. Also, the research should include measuring the rachis distance between florets, number of florets, and whole leaf area. In addition, histological cross sectioning of floral differentiation at the three-leaf stage to determine if ancymidol treatments inhibited floral differentiation growth in nonflowering genotypes as gladiolus is reported to have a visible floral spike at the three leaves stage (Schwab et al., 2015). The applied concentrations are relatively high (100 and $\left.400 \mathrm{mg} \cdot \mathrm{L}^{-1}\right)$; thus, lower concentrations would be required to study the influence of ancymidol.

\section{Literature Cited}

Ahmad, I., B.E. Whipker, and J.M. Dole. 2014. Flurprimidol preplant corm soaks or drenches affect potted gladiolus production. Acta Hort. 1104:103-108.

Aljaser, J.A. 2020. Gladiolus breeding for rapid generation cycling for potted production and the discovery of gladiolus genes, $U F C$ and FLX. University of Minnesota, Minneapolis, $\mathrm{PhD}$ Diss.

Anderson, N.O. 2019. Selection tools for reducing generation time of geophytic herbaceous peren- nials. Acta Hort. 1237:53-66, doi: 10.17660/ ActaHortic.2019.1237.7.

Anderson, N.O., J. Frick, A. Younis, and C. Currey. 2012. Heritability of cold tolerance (winter hardiness) in Gladiolus xgrandiflorus, p. $297-$ 312. In: I.Y. Abdurakhmonov (ed.). Plant breeding. IntechOpen Limited, London. doi: $10.5772 / 27328$

Anderson, N.O., J. Carter, A. Hershman, and V. Houseright. 2015. Rapid generation cycling enhances selection rate of Gladiolus xhybridus. Acta Hort. 1087:429-435.

Anderson, N.O. and A. Aljaser. 2019. Rapid cycling gladiolus. U.S. Utility Patent. U.S. plant utility patent office, Document No. 1448330011.00 - Specification - 4087289.

Ascough, G.D., N.P. Mtshali, D.I. Thompson, N.O. Anderson, J.E. Erwin, and J. Van Staden. 2006. Watsonia. Floriculture, ornamental and plant biotechnology 4:559-605.

Bailey, D.A. and W.B. Miller. 1989. Whole-plant response of Easter lilies to ancymidol and uniconazole. J. Amer. Soc. Hort. Sci. 144(3): 393-396.

Banswal, A.K. 2012. Effect of bulb sizes, growing substrates and paclobutrazol doses in potted Chincherinchee (Ornithogalum thyrsoides Jacq.). Dr. Y. S. Parmar University of Horticulture and Forestry, Solan, India, MS Thesis, Table 7.

Berghoef, J. and A.P. Zevenbergen. 1989. The effect of precooling, environmental factors and growth-regulating substances on plant height of freesia as pot plant. Acta Hort. 266:251-258.

Cohat, J. 1993. Gladiolus, p. 297-320. In: A. De Hertogh and M. Le Nard (eds.). The physiology of flower bulbs: A comprehensive treatise on the physiology and utilization of ornamental flowering bulbous and tuberous plants. Elsevier, Amsterdam

Cosgrove, D.J. and S.A. Sovonick-Dunford. 1989 Mechanism of gibberellin-dependent stem elongation in peas. Plant Physiol. 89(1):184-191.

De Hertogh, A. and M. Le Nard. 1993. The physiology of flower bulbs: A comprehensive treatise on the physiology and utilization of ornamental flowering bulbous and tuberous plants. Elsevier, Amsterdam.

De Hertogh, A.A. and R. Milks. 1989. Forcing Dutch-grown Freesias as potted plants in the US and Canada. Acta Hort. 266:115-122.

Dole, J. and H.F. Wilkins. 2005. Floriculture: Principles and species. 2nd ed. Prentice Hall, Upper Saddle River, NJ.

Ehrich, L. 2013. Flowering in South African Iridaceae, p. 248-269. In: K.G. Ramawat and J.M. Merillon (eds.). Bulbous plants: Biotechnology. CRC Press, Boca Raton, FL.

Fukai, S. 2012. Geophyte research and production in East and Southeast Asia, p. 421-434. In: R. Kamenetsky and H. Okubo (eds.). Ornamental geophytes: From basic science to sustainable production. CRC Press, Boca Raton, FL.

Goldblatt, P. and J. Manning. 1998. Gladiolus in Southern Africa. Fernwood Press (Pty) Ltd., Capetown, South Africa.

Halevy, A.H. and R. Shilo. 1970. Promotion of growth and flowering and increase in content of endogenous gibberellins in Gladiolus plants treated with the growth retardant CCC. Physiol. Plant. 23(4):820-827.

Kamenetsky, R., M. Zaccai, and M.A. Flaishman 2012. Florogenesis, p. 197-232. In: R. Kamenetsky and H. Okubo (eds.). Ornamental geophytes: From basic science to sustainable production. CRC Press, Boca Raton, FL. 
KAVB. 2014. Registraties 2013, Hillegom. 14 Nov. 2018.

Khan, F.N., M.M. Rahman, M.M. Hossain, and T. Hossain. 2011. Effect of benzyl adenine and gibberellic acid on dormancy breaking and growth in gladiolus cormels. Thai J. Agr. Sci. 44(3):165-174.

Kumar, P.N. and D.V.S. Raju. 2007. Dormancy in gladiolus: The cause and remedy $-\mathrm{A}$ review. Agr. Rev., Agr. Res. Comm. Centre, India 28(4):309-312.

McDaniel, G.L. 1990. Postharvest height suppression of potted tulips with paclobutrazol. HortScience 25(2):212-214.

Milandri, S.G., C.P. Laubscher, and P.A. Ndakidemi. 2008. Hydroponic culture of Gladiolus tristis: Application of paclobutrazol for flowering and height control. Afr. J. Biotech. 7(3):n.p.

Miller, C.T., C.M. Filios, and W.B. Miller. 2012. Effects of flurprimidol, paclobutrazol and uniconazole soaks and drenches on amaryllis (Hippeastrum) growth and development. Acta Hort. 1002:431-438, doi: 10.17660/ActaHortic.2013.1002.58.

Naor, V., J. Kigel, Y. Ben-Tal, and M. Ziv. 2008. Variation in endogenous gibberellins, abscisic acid, and carbohydrate content during the growth cycle of colored Zantedeschia spp., a tuberous geophyte. J. Plant Growth Reg. 27(3):211, doi: 10.1007/s00344-008-9048-5.

North America Gladiolus Counsel. 1999. Gladiolus parentages, Shoshone, 14 Nov. 2018.

Okubo, H. and D. Sochacki. 2012. Botanical and horticultural aspects of major ornamental geophytes, p. 77-123. In: R. Kamenetsky and H. Okubo (eds.). Ornamental geophytes: From basic science to sustainable production. CRC Press, Boca Raton, FL.
Rademacher, W. 1991. Inhibitors of gibberellin biosynthesis: Applications in agriculture and horticulture, p. 296-310. In: N. Takahashi, B.O. Phinney, and J. MacMillan (eds.). Gibberellins. Springer-Verlag, New York, NY.

Ranwala, A.P., G. Legnani, M. Reitmeier, B.B. Stewart, and W.B. Miller. 2002. Efficacy of plant growth retardants as preplant bulb dips for height control in LA and oriental hybrid lilies. HortTechnology 12(3):426-431.

Rebers, M., G. Romeijn, E. Knegt, and L.H. Van der Plas. 1994. Effects of exogenous gibberellins and paclobutrazol on floral stalk growth of tulip sprouts isolated from cooled and non-cooled tulip bulbs. Physiol. Plant. 92(4):661-667.

Schwab, N.T., N.A. Streck, C.C. Becker, J.A. Langner, L.O. Uhlmann, and B.S.M.R. Ribeiro. 2015. A phenological scale for the development of Gladiolus. Ann. Appl. Biol. 166(3):496-507, doi: 10.1111/aab.12198.

Seng, S., J. Wu, J. Liang, F. Zhang, Q. Yang, J. He, and M. Yi. 2017. Silencing GhAGPL1 reduces the quality and quantity of corms and cormels in Gladiolus. J. Amer. Soc. Hort. Sci. 142(2):119125, doi: 10.21273/JASHS03944-16.

Shaw, P.M., K.A. Schekel, and V.I. Lohr. 1991. Height control in pot-grown 'Wood Violet' Gladiolus using Ancymidol. HortScience 26(8):1089.

Simonsen, J. and A.C. Hildebrandt. 1971. In vitro growth and differentiation of Gladiolus plants from callus cultures. Can. J. Bot. 49(10):18171819.

Steinitz, B. and H. Lilien-Kipnis. 1989. Control of precocious gladiolus corm and cormel formation in tissue culture. J. Plant Physiol. 135(4):495-500.

Sudhakar, M. and S.R. Kumar. 2012. Effect of growth regulators on growth, flowering and corm production of gladiolus (Gladiolus grandiflorus L.) cv. White friendship. Ind. J. Plt. Sci. 1(2/3):133-136.

Thomas, S.G. and P. Hedden. 2006. Gibberellin metabolism and signal transduction, p. 147184. In: P. Hedden and S.G. Thomas (eds.). Annual Plant Reviews, Volume 24: Plant Hormone Signaling. Blackwell Publishing, Oxford. Tonecki, J. 1980. Effect of growth regulators on shoot apex differentiation and changes in sugars and free amino acids in gladiolus ( Gladiolus $\times$ hortorum cv. acca laurentia). Acta Hort. 109:347-356.

U.S. Department of Agriculture, National Agricultural Statistics Service. 2019. Floriculture 2018. USDA Economics, Statistics and Market Information System, Albert R. Mann Library, Cornell University, Ithaca, NY.

Whipker, B.E. and M.R. Evans. 2012. Regulation of plant growth, p. 373-390. In: P.V. Nelson (ed.). Greenhouse Operation and Management. 7th ed. Prentice Hall, Upper Saddle River, NJ.

Widmer, R.E. 1958. The determination of cold resistance in the garden chrysanthemum and its relation to winter survival. Proc. Amer. Soc. Hort. Sci. 71:537-546.

Wu, J., S. Seng, J. Sui, E. Vonapartis, X. Luo, B. Gong, C. Liu, C. Wu, C. Liu, F. Zhang, J. He, and M. Yi. 2015. Gladiolus hybridus ABSCISIC ACID INSENSITIVE 5 (GhABI5) is an important transcription factor in ABA signaling that can enhance Gladiolus corm dormancy and Arabidopsis seed dormancy. Front. Plant Sci. 6:960, doi: 10.3389/fpls.2015.00960. 